\title{
SUSTAINABLE AIRPORT ENERGY MANAGEMENT: THE CASE OF KANSAI INTERNATIONAL AIRPORT
}

\author{
Glenn Baxter ${ }^{1}$, Panarat Srisaeng ${ }^{2}$, Graham Wild ${ }^{3}$ \\ ${ }_{1,2}$ School of Tourism and Hospitality Management, Suan Dusit University, Huahin Prachaup Khiri Khan, Thailand \\ ${ }^{3}$ School of Engineering, RMIT University, Box 2476, Melbourne, Victoria, Australia
}

Received 16 April 2018; accepted 7 June 2018

\begin{abstract}
Airports play a vital role in the global air transport industry facilitating the interchange between the air and surface transport modes. The growth in passenger and air cargo traffic has resulted in increased energy requirements that airports need to satisfy. Airports are extremely energy intensive. To mitigate the environmental impact from energy consumption, airports have introduced a wide range of energy saving measures. Using a longitudinal case study research design, this study examines Osaka's Kansai International Airport sustainable energy management, energy sources, energy consumption and the methods and technologies that have been implemented to mitigate the environmental impact of energy at the airport. The study period was from 2002 until 2015. The qualitative data was examined by document analysis. Electricity, natural gas, hydrogen and wind power are the airports principal energy sources. Despite the growth in passengers and aircraft movements, the airport has been able to reduce its energy consumption. Energy-saving initiatives including the use of hydrogen, solar, and wind power, fixed electrical ground power for aircraft, widespread use of LED lighting, more efficient use of air conditioning systems and ceiling fans, and the use of low emission vehicles.
\end{abstract}

Keywords: airports; Kansai International Airport; energy; hydrogen-power; photovoltaic systems; solar panels; sustainability.

\section{Introduction}

An airport is essentially one or more runways for aircraft operations together with associated buildings or terminals where passengers or air cargo transported by aircraft are processed (Doganis, 2005). Airports are an integral component of the world air transport system - the places where airlines and the customers converge (Baxter et al., 2018; Dempsey, 2000). The basic infrastructure and facilities provided by airports compromises runways, taxiways, apron space (ramp), passenger terminals, air cargo terminals, and ground transport interchange facilities (Ashford et al., 2011). In 2016, the world's airports handled around
3.79 billion passengers and some 52.6 million tonnes of air cargo (International Civil Aviation Organization, 2017). However, airports also consume substantial amounts of energy (Ziębik and Hoinka, 2013), a byproduct of which are the $\mathrm{CO}_{2}$ emissions from energy generation. The airport industry, like many other industries, is confronting the effects of increasing environmental pressure (Graham, 2014). Hence, the global community is currently paying greater attention to the impact that airports have on the environment and airports are working to make themselves more environmentally friendly (Vanker et al., 2013). Airports have adopted a range of strategies to become more environmentally sustainable including

${ }^{1}$ Corresponding author: panarat_sri@dusit.ac.th 
initiatives to reduce their contribution to climate change through such measures as reducing their $\mathrm{CO}_{2}$ emissions and increasing energy efficiency and infrastructure resiliency (Preston, 2015).

One such airport that has sustainably managed its energy management is Osaka's Kansai International Airport, Japan's third busiest airport. Kansai International Airport has historically placed a very high focus on sustainable environmental management, and, on sustainable energy management. A key objective of Kansai International Airport is for the airport to be a smart airport that is both people and earth-friendly. Importantly, the airport is driven by its objective of becoming a pollution-free airport that also co-exists and prospers with the local Kansai region (New Kansai International Airport, 2013). Consequently, environmental management forms an integral part of Kansai International Airport governance, strategy and management system. Most importantly, the airport has implemented and adopted a wide-ranging sustainable environment policy that is underpinned by three fundamental principles - Green Innovation, Eco Operations and Eco Relations - as well as five basic sustainable environmental principles - an airport that co-exists with the local region, airports that protect a sound local environment, airports with a minimal impact on the global environment, airports that recycle resources, and airports that keep biodiversity in mind (Kansai Airports, 2016).

The objective of this paper is to analyze Kansai International Airport's sustainable energy management systems. The energy sources and consumption, as well as the methods and technologies that have been implemented to mitigate the environmental impact of the energy consumed at the airport are also empirically examined in this paper.

The remainder of the paper is structured as follows. Section 2 reviews the literature on energy management at airports. The research methodology used to underpin the case study is presented in section 3. The case study of Kansai International Airport sustainable energy management follows in section 4 . Section 5 presents the findings of the study.

\section{Background - Sustainable Airport Energy Management}

Airports are extremely energy-intensive areas (Alba and Manana, 2017). This is due to the large buildings (both passenger terminals and non-passengers areas) equipped with heating and air-conditioning systems, and the high-power demand for lighting and electric equipment and the energy requirements from the many facilities located within the airport precinct (Cardona et al., 2006). An airport's heating, ventilation and air conditioning (HVAC) system will use the largest share of energy consumed in airport terminal buildings (Akyüz et al., 2017). In addition to the provision of electrical energy required for the aids to air transport operations, for example, lighting and meteorological systems, electrical energy is also required for airport buildings, aircraft hangers and other airport facilities (Kazda et al., 2015). Thus, energy management, which includes heating, ventilation, air conditioning, and lighting, is extremely important for airports (Graham, 2014). Indeed, airports require a guaranteed, appropriately priced, and secure energy supply to meet peak demand from their service partners and passengers thereby optimizing their operational capacity. The maintenance of an ambient temperature and air quality within airport passenger terminals to ensure passenger 
comfort typically represents the single most significant contribution to energy usage and management at most airports (Thomas and Hooper, 2013).

To reduce their long-term operating costs and to ensure that energy demand can be satisfied when the needs arises, airports are placing a higher focus on energy-conservation measures in the design (and operations) of terminal buildings and infrastructure (Thomas and Hooper, 2013). Some airports have also developed and operate new powergeneration systems that provide reliable and affordable sustainable energy whilst also lowering their energy costs (Budd and Budd, 2013). Furthermore, airports often work closely with tenants, concessionaires, and service partners to reduce energy consumption through the introduction of low-energy equipment and systems (Thomas and Hooper, 2013).

There are several energy technologies that are currently being developed as energy sources for airports, including solar photovoltaic, concentrating solar power, wind power, oil and natural gas extraction, steam-generated power production and electricity transmission (Barrett et al., 2014).

Renewable energy has become an increasingly cost-effective business option for airports because of technological advancement, market maturity and public-sector investment (Barrett, 2015). Airports have characteristics that enhance the financial viability of on-site renewable energy, particularly for solar photovoltaics (PV). Airport land and buildings can provide suitable sites for solar facilities that otherwise do not generate financial benefit. The open landscape and geographic position of airports necessary for safe airport management also facilitates the capture of natural resources that fuel renewable energy (Barrett, 2015). In addition, airports can also achieve potential returns from selling surplus energy back into the power grid. Renewable energy technology has increasingly developed over the past 20 years (McGormely, 2011). Energy consumed by airports can be broadly split into the energy consumed by the airside activities undertaken at the airport as well as the energy consumed in the provision of the airport's landside area activities. In the airport's airside area, energy requirements include the fuel that is consumed by aircraft during the landing and take-off (LTO) cycles. Also, ground vehicles serving aircraft at the apron/gate complex consume energy. In the airport landside area, the primary consumers of energy are the airport ground access systems/modes and passenger and air cargo terminals as well as other administrative buildings serving the airport. In all cases, the primary energy sources are from non-renewable fossil fuels and to a moderate degree from renewable wind, water, and solar sources (Janić, 2011).

Electrical energy is normally sourced from different sources and is supplied directly to the airport through dedicated sub-stations. This energy is principally consumed for heating, cooling, lighting, and operating the airport's facilities, equipment, and other devices in the processes of servicing passengers and their baggage and air cargo consignments in passenger and cargo terminals, respectively. Electrical energy is also consumed in the provision of heating, cooling (air conditioning), and lighting other administrative buildings at airports (Janić, 2011). 


\section{Research Method}

This study used a qualitative longitudinal research design (Court, 2010; Hassett and Paavilainen-Mäntymäki, 2013) that was exploratory in nature. The study followed an inductive approach using both qualitative and quantitative research methods (Hair et al., 2015; Lancaster, 2005). The goal of such an approach is to expand and build theories rather than perform statistical analysis to test a certain hypothesis (Rahim and Baksh, 2003). A case study, whilst like an experiment, does not represent a sample, and the researcher's role is to expand and generalize theories (analytical generalization) and not to enumerate frequencies (statistical generalization) (Yin, 2009).

The qualitative data for this study was obtained from a range of documents, including the airport's annual environmental and Smart Island reports Qualitative data was also gathered from web sites, air transport and airport industry-related magazines, and press articles. The study therefore used secondary data analysis to investigate the research problem. The three principles of data collection suggested by Yin (2017) were followed in this study: the use of multiple sources of case evidence, creation of a database on the subject, and the establishment of a chain of evidence.

The empirical data collected for the case studies was examined using document analysis. Document analysis is often used in case studies and focuses on the information and data from formal documents and company records (Oates, 2006; Ramon GilGarcia, 2012). The documents collected for the study were examined according to four criteria: authenticity, credibility, representativeness and meaning (Payne and
Payne, 2004; Scott and Marshall, 2009). Prior to conducting the formal analysis of the documents gathered in the study, the context in which the documents were created was determined and the authenticity of the documents was assessed (Love, 2003). Authenticity involves an assessment of the collected documents for their soundness and authorship. Scott and Marshall (2009, p.188) note that 'soundness refers to whether the document is complete and whether it is an original and sound copy. Authorship relates to such issues as collective or institutional authorship. In this study the source of the case study documents was Kansai International Airport. The documents were available in the public domain. The credibility criterion concerns the accuracy and sincerity of a document. The representativeness criterion involved an assessment of the availability and survival of the documents gathered. The fourth criterion, meaning, is a most important matter and occurs at two levels. The first is the literal understanding of a document, by which is meant its physical readability, the language used and whether it can be read, as well as the date of the document (Scott and Marshall, 2009).

The documents collected in this study covered the period 2002 to 2015 . All the gathered documents were downloaded and stored into a case study database (Yin, 2017). The documents collected for the study were all in English. Each document was carefully read, and key themes were coded and recorded. Triangulation was also used to avoid potential bias, add discipline to the study's qualitative research, to ensure stronger accuracy, and to demonstrate verification of the data. This approach helped verify the themes that were detected in the documents gathered in the study (Morris, 2017). 


\section{Case Study}

\subsection{Kansai International Airport: A Brief Overview}

Kansai International Airport is located in the southern area of the very large Osaka Bay in the Kansai Region of western Japan (Morikawa et al., 2007). The airport was constructed as a man-made island five kilometres off-shore in Osaka Bay (Edgington, 2000). The concept for Kansai International Airport appeared in 1968, following a survey of potential airport sites in the Osaka area. Due to the high population density in the Osaka region and the scarcity of available land, a man-made island was determined to be the only feasible option for the new airport. Noise pollution as well as other environmental concerns assisted the Ministry of Transport to permit construction of the airport in 1986 (Moorman, 1994). The airport, which cost around \$USD 13 billion (Ishikura et al., 2005), commenced operations in 1994 as Japan's first 24-hour airport and now plays a key role as an important international hub in the global air transport network (Morikawa et al., 2007).

In the Kansai International Airport first phase project, an airport island with a land area of approximately 510 hectares was reclaimed on which a 3,500 metre runway and the related infrastructure were built (Morikawa et al., 2007). During the early 1990 s, the number of aircraft departures and arrivals during morning and early evening peak periods exceeded the airport's handling capacity of 30 aircraft movements per hour. Thus, to accommodate demand and operate as an international hub airport, the second phase of the airport development commenced in 1999 (Furudoi, 2010). The second phase Kansai International Airport project involved the development of a further man-made island 545 hectares in size. The airport's second runway, which is 4,000 metres in length, was also built on the island (Dempsey, 2000). The second island is located 200 metres off-shore from the initial island (Morikawa et al., 2007). The airport officially opened its second runway in 2007 (Kansai International Airport Company Ltd, 2007) thereby providing the airport with the ability to become an international hub.

Kansai International Airport has two passenger terminals. Terminal One has a total floor area of 303,944 square metres. The domestic departures floor is located between the International Arrivals (Floor 1) and the International Departures on Floor 4. Terminal 2 is dedicated to the lowcost carriers (LCCs) serving the airport and has a total floor area of 29,680 square metres (Kansai Airports, 2018a). It has been estimated that there are around 15,000 people working at the airport.

Figure 1 shows the total annual domestic and international passengers at Kansai International Airport since its inception of operations in 2002 to 2015 . The impacts of the aftermath of $9 / 11$ and the 2008 global financial crisis (GFC) can clearly be observed in the both the annual enplaned domestic and international passengers. Figure 1 also shows that international passengers constitute the largest number of passengers travelling via the airport. Domestic flights are operated from Kansai International Airport; however, Osaka International Airport primarily acts as the major local domestic terminal for the city of Osaka. Furthermore, since 2012, the low-cost carriers (LCCs) have emerged in the Japanese market and appear to be particularly important for Kansai International Airport. Peach Aviation (a joint venture including 
ANA) is now one the airport's leading airlines in terms of weekly departures. In July 2012, Jetstar Japan, also an LCC, commenced business at Kansai International Airport.
Like Peach Aviation, Jetstar Japan has also expanded their services from the airport. The LCCs are therefore helping to drive traffic growth at the airport (Anna Aero, 2014).

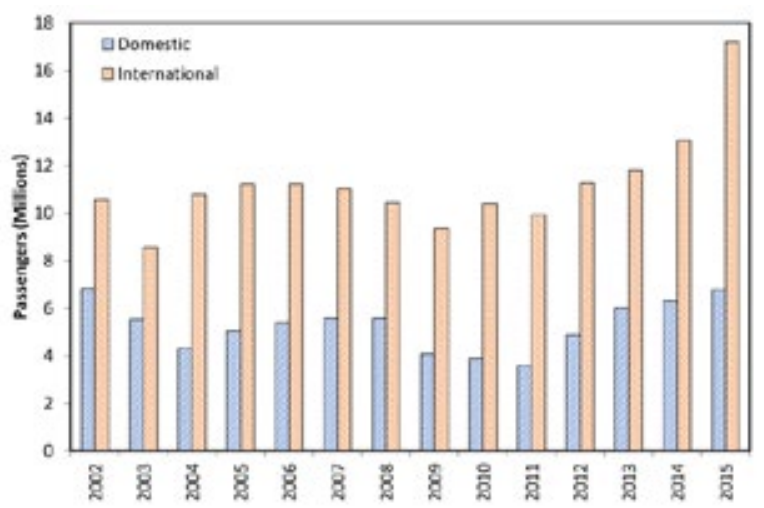

Fig. 1.

Annual Enplaned Domestic and International Passengers at Kansai International Airport: 2002-2015 Source: data derived from (Kansai Airports, 2018b)

\subsection{Kansai International Airport Management Plan}

Energy management is a critical aspect of airport operations as airports are extremely energy-intensive areas. A key objective of Kansai Airports, the airport operator, is that electricity consumption and its generation at Kansai International Airport is to be managed in an integrated way and that energy conservation is to be promoted, including the reduction of electricity during peak times at the airport (Kansai Airports, 2016).

\subsection{Energy Sources at Kansai International Airport}

As noted earlier, electrical energy is normally sourced from various sources and is supplied directly to the airport through dedicated sub-stations. The principal energy source at
Kansai International Airport is electricity, which is purchased from the municipal authorities. Other energy sources include natural gas, solar power, hydrogen as well as wind power.

\subsection{Kansai International Airport Energy Consumption}

\subsubsection{Annual Electricity Consumption at Kansai International Airport}

The total annual energy consumption at Kansai International Airport from 2002 to 2015 that is managed by the New Kansai International Airport Company is presented in Figure 3. During the period 2002 to 2015, the airport was able to reduce its annual electricity consumption from a high of $122 \mathrm{GWh}$ in 2002 to $102 \mathrm{GWh}$ in 2015 (Figure 3). As discussed below, the airport has implemented a wide range of energy management initiatives that 
have played a very important role in reducing the airport's energy consumption throughout this period. This is shown in the year on year percentage change line graph, which is more negative than positive (more values below the zero line than above).

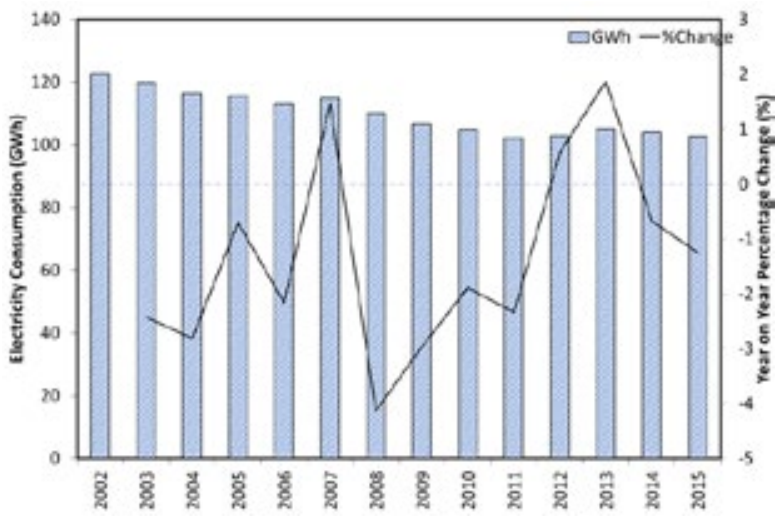

Fig. 3.

Annual Electricity Consumption at Kansai International Airport and Year-on-Year Change (\%): 2002-2015 Source: data derived from (Kansai Airports, 2016; New Kansai International Airport Company 2013)

\subsubsection{Annual Energy Consumption Per Passenger and Aircraft Movement}

Airport energy efficiency can be measured by energy consumed per passenger and energy consumed per aircraft movement (Janić, 2011). Figure 4 shows the annual energy per passenger at Kansai International Airport from 2002 to 2015. Despite the increase in passengers (and aircraft movements), the airport has been able to reduce the energy consumption per passenger from 2010 to 2015; which is illustrated by the year-on-year percentage change line graph being more negative.

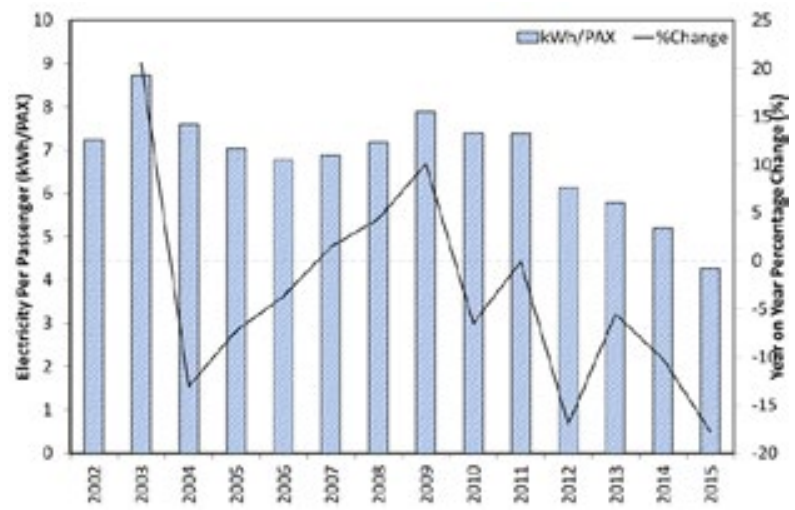

Fig. 4.

Energy Per Passenger at Kansai International Airport and Year-on-Year Change (\%): 2002-2015

Source: data derived from (Kansai Airports, 2016; New Kansai International Airport Company 2013) 
The annual energy per aircraft movement at Kansai International Airport from 2002 to 2015 is shown in Figure 5. Like the trend in energy per passenger, Kansai International Airport has been able to reduce the energy per aircraft movement from a high in 2003 to a low in 2015. This is despite the increased domestic and international aircraft movements at the airport.

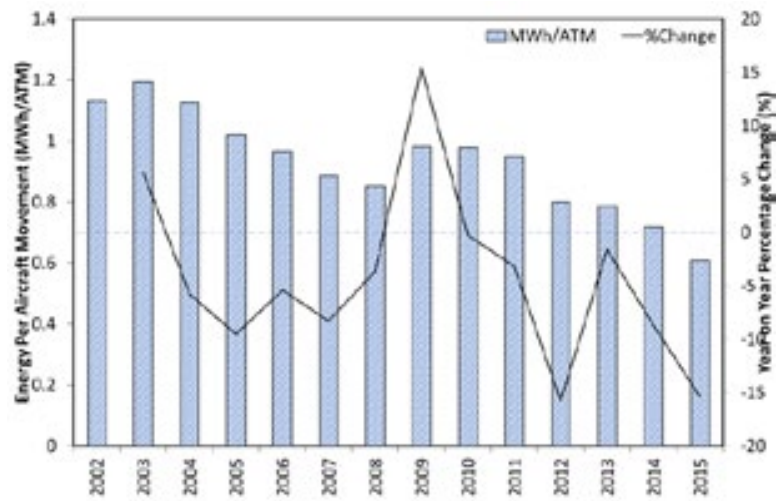

Fig. 5.

Energy per Aircraft Movement at Kansai International Airport and Year-on-Year Change (\%): 2002-2015 Source: data derived from (Kansai Airports, 2016; New Kansai International Airport Company 2013)

\subsubsection{Annual Energy Consumption for Cooling at Kansai International Airport}

The weather in Osaka-city is typically quite mild. However, during the city's summer weather can be both hot and humid (Tsutsui, 2013). Thus, it necessary for Kansai International Airport to provide cooling for passenger terminals and other airportrelated buildings during such times. Figure 6 shows Kansai International Airport's total annual consumption for cooling from
2002-2015. During this period the annual energy consumption for the provision has remained relatively constant. From 2011 to 2015 , the average annual consumption for cooling has been around $241 \mathrm{TJ}$, which represents a significant reduction on the energy consumption for cooling that was recorded in the 2002 and 2004 fiscal years (Figure 6). The relatively constant state is highlighted by the year-on-year percentage change line graph, which is fairly balanced about the zero line. 


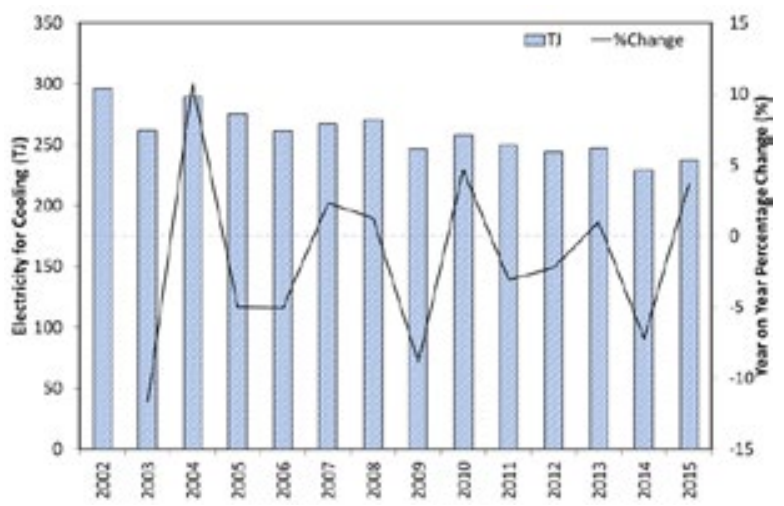

Fig. 6.

Energy for Cooling at Kansai International Airport and Year-on-Year Change (\%): 2002-2015

Source: data derived from (Kansai Airports, 2016; New Kansai International Airport Company 2013)

\subsubsection{Annual Energy Consumption for Heating at Kansai International Airport}

The average maximum and minimum winter temperatures in Osaka are around $10 \mathrm{C}$ and 3C, respectively (Climates to Travel, 2018). Thus, during these periods of wintry weather, Kansai International Airport is required to heat airport buildings and offices. The annual energy required for heating at the airport from 2002 to 2015 is presented in Figure 7.
As can be seen in Figure 7, there have been marked spikes in the annual energy acquired for heating in 2003, 2005, 2007, 2011, and 2012 (as seen in the year on year percentage change line graph). These spikes could be attributed to the cold winter temperatures recorded in Osaka. Also, Kansai International Airport opened its new low-cost carrier terminal (Terminal 2) on the 29th October 2012, which increased the size of the facilities that require heating.

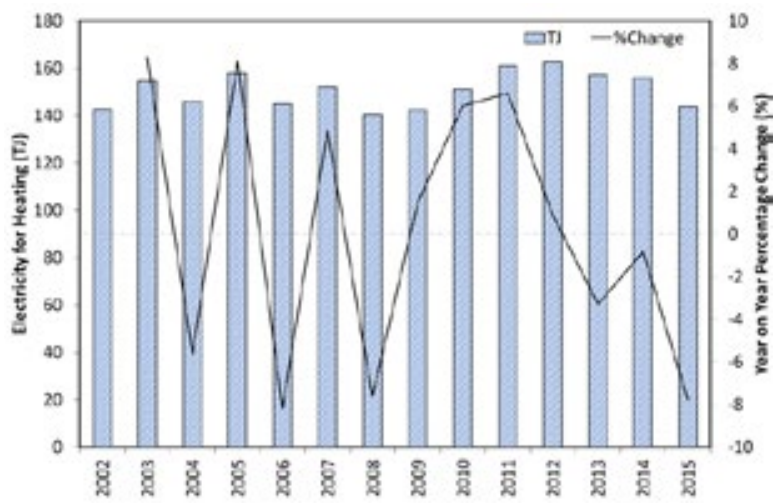

Fig. 7.

Energy for Heating at Kansai International Airport and Year-on-Year Change (\%): 2002-2015 Source: data derived from (Kansai Airports, 2016; New Kansai International Airport Company 2013) 


\subsubsection{Annual Natural Gas Consumption at Kansai International Airport}

In addition to the electricity supplied from the municipal authorities, Kansai International Airport also purchases supplies of natural gas. Figure 8 shows the total annual quantities of natural gas purchased by the airport during the period 2002 to 2015 . As can be seen in Figure 8, from 2007 to 2012 , the annual volumes of natural gas declined. The heating and cooling for the airport's air conditioning system and the supply of hot water comes from the Kansai International Airport Heating and Cooling Supply Company (KHC), which is a subsidiary of Kansai Airports (New Kansai International Airport Company, 2014a). The large spikes in natural gas usage in 2014 and 2015 can be attributed to the natural gas usage requirements of Kansai International Airport Heating and Cooling Supply Company (KHC). This company's data was incorporated into the Kansai Airport's annual environmental reports in 2014. Because of this reporting change, the year-on-year changes recorded in 2014 and 2015 showed marked spikes because of the Kansai International Airport Heating and Cooling Supply Company (KHC) natural gas consumption.

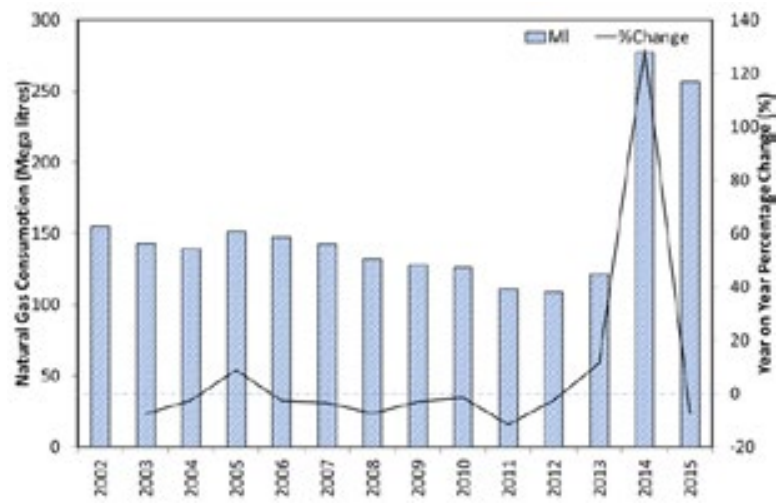

Fig. 8.

Kansai International Airport Total Annual Natural Gas Consumption and Year-on-Year change (\%): 2002-2015

Note: Primary energy managed by the New Kansai International Airport Company Source: Data derived from (Kansai Airports, 2016; New Kansai International Airport Company 2013)

In Figure 8, the values for 2014 and 2015 are significantly greater than those for the proceeding years (specifically, the values for these two years are greater than 3 standard deviations above the mean for 2002 to 2013). As such, a two-stage statistical analysis has been utilized. First, to assess the statistical significance of the change from 2013 to 2014, a two-sample $t$-test was utilized. The twosample $t$-test assuming unequal variance between the years 2002-2013 and 2014-2015, yielded a $t$-statistic of 12.0 , which is greater than the critical value of 6.31 . Hence, we can conclude that there has been a statistically significant increase from 2002-2013 to 20142015 in the volume of natural gas consumed. 
The result of the $t$-test indicates that a significant variable needs to be factored into the regression analysis to capture this increase from 2013 to 2014 . To facilitate the regression analysis is it therefore necessary to utilize multiple linear regression, with an additional dummy variable to account for the observed jump. Thus, a dummy variable has a value of 0 from 2002 to 2013, and a value of 1 for 2014 to 2015 ( 0 = no contribution, $1=$ contribution from unknown variable). To analyze the significance of this model for natural gas consumption at Kansai International Airport, an F-test was conducted. The statistics tested the following hypotheses:

Null hypothesis $\left(\mathrm{H}_{0}\right): \quad \beta_{1}=\beta_{2}=0$ Alternative hypothesis $\left(\mathrm{H}_{\mathrm{A}}\right): \beta_{1}>0, \beta_{2}<0$

For Kansai International Airport's natural gas consumption, the F-statistic is 272 . The corresponding critical value with degrees of freedom 2 and 11 at the $99 \%$ confidence level for a one tailed test is 5.7. As the calculated $F$-statistic is greater than the critical value, the null hypothesis can be rejected, and we can conclude that the model is statistically significant, and that the volume of natural gas consumption has decreased with time. It also can be concluded that some additional unknown variable has resulted in an increase in natural gas consumption between 2013 and 2014. It is likely that additional processes utilizing significantly larger quantities of natural gas came online in 2014. For example, ground vehicles utilizing natural gas, or changes in water heating may have been used; however, no explanation can be found to define this variance. Figure 9 is a plot showing the "line of best fit" for the model over the actual values of Kansai International Airport's annual natural gas consumption.

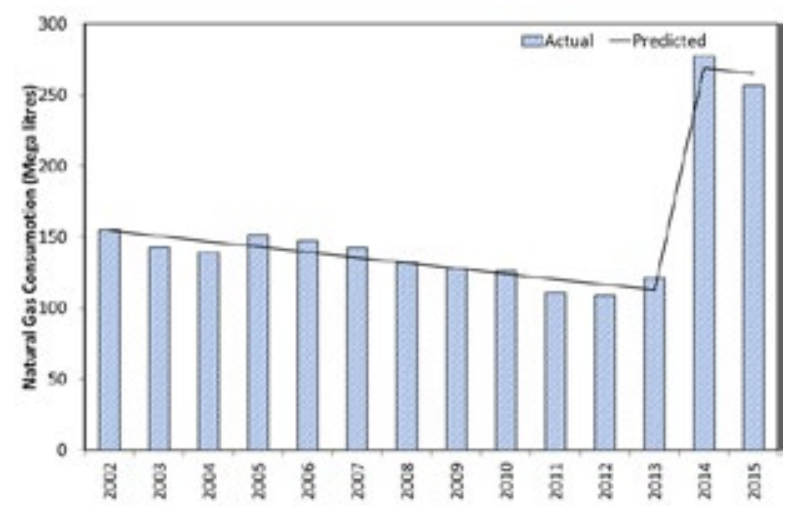

Fig. 9.

Plot Showing the Actual Kansai International Airport Natural Gas Consumption: 2002-2015 and the Gas Consumption Predicted by the Multiple Linear Regression Model

Note: Primary energy managed by Kansai International Airport Company

Source: Data derived from (Kansai Airports, 2016; New Kansai International Airport Company 2013) 


\subsubsection{Annual Energy Consumption Per Unit of Floor Space}

The annual energy consumption per unit of floor space (crude oil equivalent) at Kansai Airport from 2003 to 2015 is presented in Figure 10. The first notable feature is that the year on year percentage change line graph is always negative, indicating that there has been a continuous reduction in the crude oil equivalent at Kansai Airport from 2003 to 2015 . It is also interesting to note that over this period, the actual area of floor space has increased. The lowcost carriers terminal (Terminal 2) was opened in October 2012. Kansai Airports also completed the expansion of Terminal 2 in January 2017. As noted earlier, the main terminal building has $116,126 \mathrm{~m}^{2}$ of floor space, whilst Terminal 2 now has $66,000 \mathrm{~m}^{2}$ of floor space (Kansai Airports, 2018b).

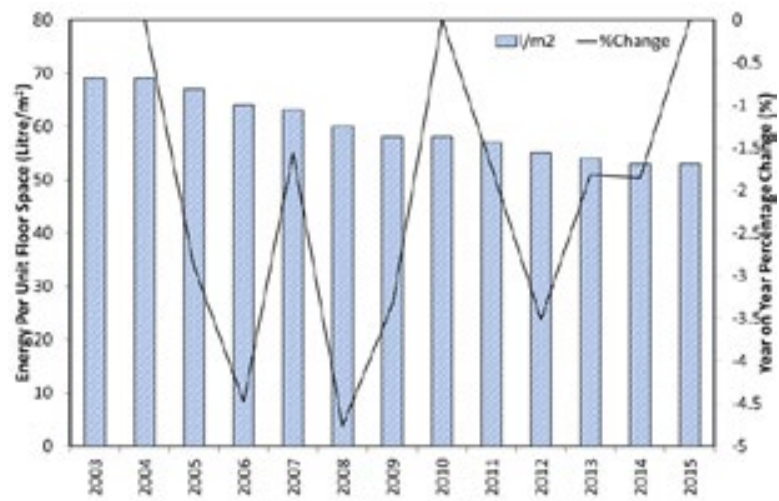

Fig. 10.

Kansai International Airport Total Annual Energy Consumption per Unit of Floor Space (Crude Oil Equivalent) and Year-on-Year Change (\%): 2003-2015

Note: 2002 data is not available

Source: data derived from (Kansai Airports, 2016; New Kansai International Airport Company 2013)

\subsection{Kansai International Airport Energy Saving Initiatives}

In recent years, Kansai International Airport has placed a high focus on sustainable energy management and has implemented a wide range of initiatives (measures) aimed at reducing the airport's environmental impact and each of these are examined in the following section.

\subsubsection{Energy Savings from the Use of Passenger Terminal Ceiling Fans}

In 2014, the airport in conjunction with the University of Tokyo conducted a research project whose aim was to better understand the seasonal trends in electrical energy consumption at the airport. The study found that electrical energy consumption is very high in both the summer and winter 
periods, with winter mornings tending to have especially high consumption during the hours that the air conditioning system is in operation. Consequently, the Kansai International Airport Energy Conservation Committee conducted a variety of tests in relation to the introduction of new energysaving technologies, such as ceiling fans in the terminal buildings. The effectiveness of the use of ceiling fans was confirmed. In the 2013 fiscal year, the airport installed two ceiling fans, measuring three metres in diameter, in the Terminal 2 international passenger flight waiting lounge, and confirmed the energy savings effects. This initiative resulted in a 28 per cent reduction in electricity consumption for the air conditioning system operating in that area, without having any negative impact on the indoor air temperatures (New Kansai International Airport Company, 2014a).

\subsubsection{Efficient Operation of Passenger Terminal Air Conditioning Systems Using Information Technology (IT)}

As previously noted, airports are extremely energy-intensive areas. The passenger terminal(s) typically consume substantial amounts of energy, which is used primarily for the provision of air conditioning as well as lighting. At Kansai International Airport the main passenger terminal is comprised of a very large continuous stretch of space that has no partitions and is constantly used by the airport's customers. Thus, in principle, all areas of the terminal must remain in operation from the first flight of the day through to the final flight of the day. This results in the use of a large amount of energy (Kansai International Airport Company, Ltd., 2012). Because passengers are dispersed throughout the terminals in each gate lounge, to save power, the airport developed a fully automated energy-saving air conditioning system. The system links the on-off function of the air conditioning equipment with the airport's passenger information system (PIS). The results of this initiative are as follows:

- A shortening of the gate lounge air conditioning operation times by approximately 6 hours per day;

- A reduction in the energy consumption of the air conditioning system of approximately 34 per cent;

- Approximately 1,000 kilo litres/year (crude oil equivalent) saving in the total amount of energy conserved at the airport;

- A reduction in carbon dioxide $\left(\mathrm{CO}_{2}\right)$ emissions of approximately 1,500 tons/ year; and

- A reduction in the heating costs of around $¥ 65$ million/per year (Kansai International Airport Company, Ltd., 2012, p. 16).

\subsubsection{Hydrogen Energy Model: Kansai International Airport Hydrogen Grid Project}

Kansai International Airport is actively pursuing the use of clean energy sources as part of its commitment to sustainable airport operations. This objective is guided by the airport's Smart Island Vision. In May 2014, a decision was taken to proceed with the full-scale launch of the airport's Hydrogen Grid Project (Figure 11). This is an important pillar of the airport's Smart Island Vision. The Hydrogen Grid Project received the support of Japan's national government and made use of its "Comprehensive Special Zones for International Competitiveness Development program" (New Kansai International Airport Company, 2015b). 
The use of hydrogen as an energy source has been attracting considerable attention as it has been suggested that hydrogen is the ultimate clean energy source. The airport's Hydrogen Grid Project was the first in Japan to demonstrate the large-scale introduction and use of hydrogen energy at the airport's facilities (New Kansai International Airport Company, 2014b).

Kansai International Airport was the first Asia-based airport to introduce the use of hydrogen powered forklifts. The use of these forklifts will result in a reduction of emissions of $\mathrm{CO}_{2}$, as well as providing an improvement in working efficiency. The forklift can be refueled in approximately three minutes and does not require the recharging or change of batteries (New Kansai International Airport Company, 2015a). In March 2016, All Nippon Airways and the Japan Airlines Groups commenced the use of two fuel-cell hydrogen powered fork lifts. The forklifts use the same type of fuel cell as the hydrogen-powered Mirai car (Kansai Airports, 2016).

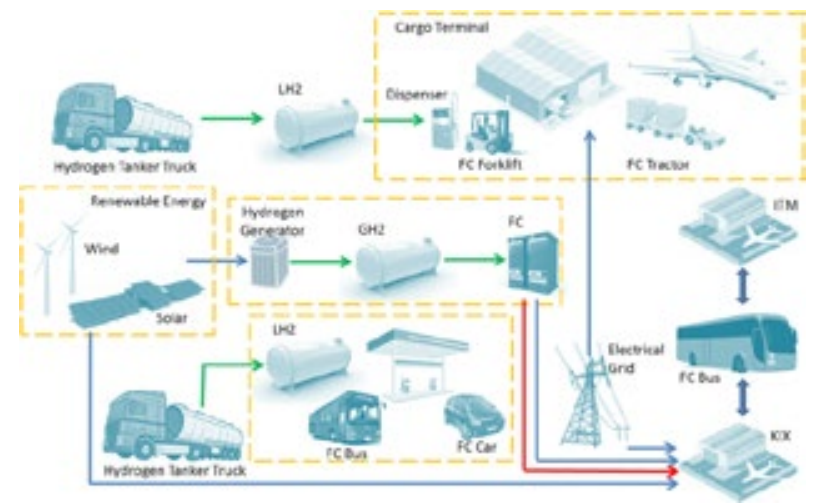

Fig. 11.

Kansai International Airport Hydrogen Grid Concept

Legend: FC fuel cell, GH2 gaseous hydrogen, LH2 liquid hydrogen, ITM Osaka International Airport, KIX Kansai International Airport

Source: Based on (New Kansai International Airport Company Ltd, 2014a, 2015a)

In addition, over the past decade, hydrogen and fuel cell technologies have been viewed as one of the viable solutions to mitigate air pollution issues. Thus, a way of mitigating the pollution from airport ground service equipment (GSE) could come from the replacement of the traditional GSE propulsion system, that quite often are based on fossil fuels, with hydrogenbased fuel cell technologies. Fuel cells are systems that can generate energy from fuel much more efficiently than the traditional internal combustion (IC) engines. The other advantages of fuel cells are that they completely avoid the emissions of carbon dioxide $\left(\mathrm{CO}_{2}\right)$, carbon monoxide (CO), hydrocarbons (HCs), nitrogen oxides $\left(\mathrm{NO}_{\mathrm{x}}\right)$, and carcinogenic substances (Testa et al., 2014). Kansai International Airport has adopted the use of hydrogen as a fuel source for airport ground service equipment (GSE) and vehicles operating at the airport. In May 
2007, Kansai International Airport installed a hydrogen station at the airport. Vehicles that are running on hydrogen-powered engines are operated for commercial use. In addition, between October 2012 and March 2014, buses that are powered by hydrogen fuel cells, were in trial operation as shuttle buses operating between the Aeroplaza and Terminal 2. The airport received positive feedback from the passengers regarding their quietness during this trial period. Also, it was estimated that around 3.2 tons of $\mathrm{CO}_{2}$ emissions were reduced from the use of these buses during the trial (Kansai Airports, 2016). Since the 2010 fiscal year, the airport has conducted trial operations of a mobile power supply truck that is equipped with fuel cells that run on pure hydrogen. The truck has been used during dragon boat competitions as well as other outdoor events (New Kansai International Airport Company Ltd, 2013). In addition, it was anticipated that fuel-cell vehicles (FCVs) would be sold in Japan in the 2015 fiscal year onwards and the airport is thus promoting the construction of hydrogen fueling stations along the Phase 2 island main roads ( New Kansai International Airport Company Ltd, 2014a).

It is important to note, however, that the production of hydrogen from non-renewable feedstock (coal, natural gas, and oil), however, causes the production of carbon dioxide $\left(\mathrm{CO}_{2}\right)$ gases (Balachandar et al., 2016; Dincer and Joshi, 2013) which are detrimental to the environment. In contrast, hydrogen produced using renewable sources would not create greenhouse emissions or, in the case where biomass is used as the feedstock, then this would create near zero emissions (Yeang and Woo, 2010). Thus, it is important for airports to consider sourcing hydrogen produced from renewable energy sources to ensure the least environment impact of using this energy source.

\subsubsection{Kansai International Airport Energy Conservation Committee}

In the 2002 fiscal year, the Kansai International Airport Energy Conservation Committee was established. The aim of the committee is to improve energy efficiency at the airport. The committee meets on an annual basis and discusses energyefficiency policies and measures and works on operational improvements and upgrade projects. Other energy conservation activities include the inspection of interior lighting and air conditioning/temperature, by conducting "Energy Conservation Patrols" (New Kansai International Airport Company Ltd, 2015a).

In July 2006, Kansai International Airport's Passenger Terminal Building and the Aeroplaza complex were designated as a Class 1 Specific Plant, which obligated the airport to implement energy savings as prescribed in the Law Concerning the Rational Use of Energy (enacted in April 2009). A Class 1 specific plant under the Energy Conservation Law is a plant that uses 3,000 kilolitres (KL) or more of fuel and $1,200 \mathrm{kWh}$ or more of electricity. Such plants are obligated to create and submit an energy conservation plan (medium- and-long-term plan) and periodically report their results (Kansai International Airport Company Ltd, 2007, p. 21).

\subsubsection{Light-Emitting Diodes (LEDs)}

Light-emitting diodes (LEDs) are a practical option for airports due to the requirement for coloured light as well as low light output requirements. Airports all around the world are increasingly transitioning to the use of 
LED systems (Freyssinier, 2014). Kansai International Airport is one such airport that is working toward the full transition to LED lighting, and has been moving steadily to convert to LED equipment not only for aviation lighting but also in existing facilities. Kansai International Airport has installed LEDs as the taxiway edge lights on Runway 2 . Around 700 blue LED lights are used to indicate the edge of the taxiway along the approach to the airport's apron area. These taxiway edge lights are among the approximately 3,500 lights that compromise the aviation lighting system on the Phase 2 Island during the times when Runway 2 is in service (New Kansai International Airport Company Ltd, 2015a).

LED lights are also highly energy-efficient, consuming around about one-third the electricity as compared to the conventional halogen lights that were previously used at the airport. LED light sources also have significantly lower maintenance costs due to their lower power requirements and long life (Ehiorobo, 2017). Kansai International Airport has observed that their LED lighting running costs are significantly lower, and the LED lights service lives are anywhere from 50 to 100 times longer. In addition to the lower operating costs of the LED lighting, in the 2013 fiscal year the airport boosted the efficiency of apron lighting and combining reflective displays with LED units in road information signage. This initiative combined with the other energy saving initiatives undertaken in the 2013 fiscal year enabled the airport to cut around 727 tons of carbon dioxide $\left(\mathrm{CO}_{2}\right)$ from its total annual emissions (New Kansai International Airport Company Ltd, 2015a).

In the 2015 fiscal year, lighting in the parkade and airport station concourse, Aeroplaza building, and other areas was converted to LEDs (2,550 fixtures). Also, in 2015 the airport undertook taxiway improvements associated with the Phase 2 island terminal. As part of this project, 664 LED units that are used for taxiway centre line lights, taxiway edge lights, and aircraft taxiing guidance signs were installed. The airport estimates that these LEDs will reduce energy consumption by 70 to 90 per cent as compared to the use of conventional halogen bulb lighting (Kansai Airports, 2016).

\subsubsection{Introduction of Low-Emission Vehicles}

Air pollution at an airport is not only produced by aircraft during the landing and take-off (LTO) cycle but also from the ground service equipment (GSE) used during airport ground handling operations (Testa et al., 2014). Hence, in addition to the carbon dioxide $\left(\mathrm{CO}_{2}\right)$ emissions generated by aircraft, aircraft ground operations carbon dioxide $\left(\mathrm{CO}_{2}\right)$ emissions can also be significant at airports (International Airport Review, 2010). The replacement of internal combustion engine powered airport ground support vehicles and equipment could potentially reduce carbon monoxide (CO), hydrocarbons (HC), nitrogen oxides (NOx), and particulate matter (PM) (Gellings, 2011). Kansai International Airport is gradually introducing "eco-cars" (electric, fuel cell, natural gas, hybrid, plug-in hybrid, and ultrafuel-efficient vehicles) when vehicles require replacement. At the same time, the airport has been encouraging contractors to convert their fleets to low-emission vehicles (New Kansai International Airport Company Ltd, 2015a). In August 2006, Kansai International Airport and Rinku Town were selected as a region for the dissemination and promotion of the use of compressed natural gas (CNG) powered vehicles (Kansai International Airport Company Ltd, 2007). 
Thus, another important sustainable environment strategy implemented by Kansai International Airport has been a policy to gradually introduce "eco-cars" (electric, fuel cell, natural gas, hybrid, plug-in hybrid, and ultra-fuel-efficient vehicles) when vehicles are being replaced or when other opportunities arise. The airport is also encouraging companies and operators providing services at the airport to convert their fleet to "ecocars". The Kansai International Airport Taxi Operators Council, for example, is introducing eco-friendly vehicles ( $\mathrm{New}$ Kansai International Airport Company Ltd, 2014b). Electric-powered cars have several important environmental benefits: a reduction in noise and pollution, and they also help to reduce the reliance of transport modes on oil - providing, of course, that the power is produced from fuels other than oil. Importantly, electric-powered vehicles can also be used to reduce carbon emissions (Larminie and Lowry, 2012). In March 2015, there were 329 low emissions "Eco-cars" (vehicles) authorized to operate inside the airport's restricted areas, of these, 191 were electric-powered vehicles ( New Kansai International Airport Company Ltd, 2015a). Figure 12 shows the trend in the number of "eco-cars" operating at the airport and the year-on-year change (\%) registered and authorized to operate at the airport from 2006 to 2015 . It can be seen in Figure 12 that there has been a clear upward trend from 2006 to 2012 in both the number of low emissions "eco-cars" used at the airport. However, in 2014, there was a marked reduction in the number of "ecocars" operating at the airport Figure 12. This decline was due to a new Japanese stricter local government regulation on eco-engine vehicles.

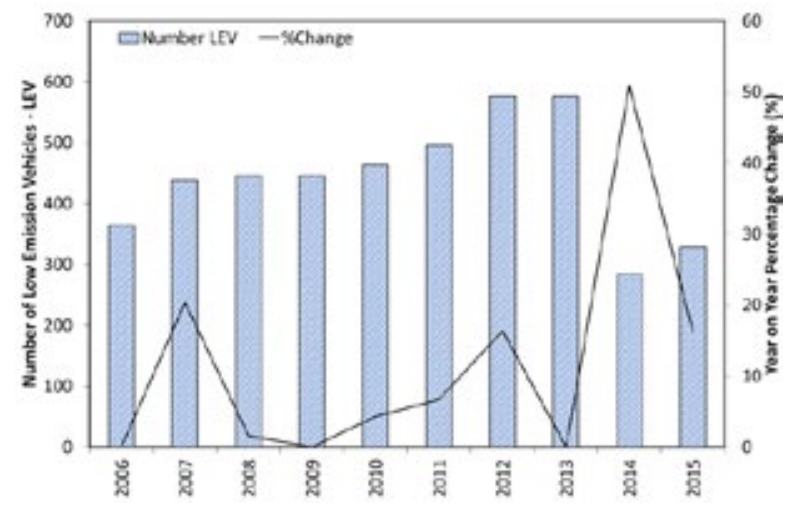

Fig. 12.

The Number of Low-Emission Vehicles Operating at Kansai International Airport and the Year-on-Year Change (\%): 2006 to 2015

Note: data prior to 2006 is not available

Source: data derived from (Kansai Airports, 2016; New Kansai International Airport Company Ltd, 2013, 2014a, 2015a) 
In Figure 12, the values for 2014 and 2015 are significantly less than those for the proceeding years, as can be seen in the yearon-year percentage change line graph. As such, two-stage analysis has been utilized. First, to assess the statistical significance of the change from 2013 to 2014, a two-sample $t$-test was utilized. The two-sample $t$-test assuming unequal variance between the years 2006-2013 and 2014-2015, yielded a $t$-statistic of 4.93 , which is greater than the critical value of 2.13 . Hence, we can conclude that there has been a statistically significant decrease from 2006-2013 to 2014-2015 in the number of low emission vehicles. The result of the $t$-test indicates that a significant variable needs to be factored into the regression analysis to capture this increase from 2013 to 2014 . To facilitate the regression analysis is it therefore necessary to utilize multiple linear regression, with an additional dummy variable to account for the observed jump. Thus, a dummy variable has a value of 1 from 2006 to 2013, and a value of 0 for 2014 to 2015 ( $0=$ no contribution, 1 = contribution from unknown variable).

For Kansai International Airport's low emission vehicles, the F-statistic is 71 . The corresponding critical value with degrees of freedom 2 and 7 at the $99 \%$ confidence level for a one tailed test is 7.2. As the calculated F-statistic is greater than the critical value, the null hypothesis can be rejected, and we can conclude that the model is statistically significant and that the number of low emission vehicles has increased with time, and some additional unknown variable has resulted in a decrease in low emission vehicles between 2013 and 2014. One possible explanation for this could be fleet renewal, and the use of alternative emission vehicles, for example natural gas power vehicles, which also correlates to the findings of Section 4.4.5; however, no official explanation can be found to define the dummy variable

In addition, charging stations are required to promote the greater use of electric vehicles at the airport. Consequently, Kansai International Airport has installed electric vehicle charging stations (New Kansai International Airport Company Ltd, 2015a). Kansai International Airport installed rapidcharging stations for electric vehicles in the Observation Hall parking lot in March 2011, and their operation commenced the following month. The chargers used for household use typically take between eight to ten hours to charge a vehicle. However, the rapid chargers installed at Kansai International Airport can charge a vehicle battery to around 80 per cent of capacity within approximately thirty minutes. In December 2012, the airport installed two regular chargers (plug-in type) in the airport car parks P1 and P2 (New Kansai International Airport Company Ltd, 2014a). A rapid charger, which is available 24 hours per day, was installed in Parking Lot 5 at Terminal 2 in June 2014 (New Kansai International Airport Company Ltd, 2014b). With these charging facilities, customers can now come arrive at the airport with the knowledge that they will be able to charge their electric vehicles. The airport plans to continue with these initiatives to be not only more environmentally friendly, but also create greater convenience for customers as well (New Kansai International Airport Company Ltd, 2014a).

\subsubsection{Promoting the Use of Fixed Electrical Ground Power (FEGP) Systems for Aircraft Ground Servicing}

To reduce emissions of $\mathrm{CO}_{2}$ and air pollutants from the use of aircraft auxiliary power units 
(APUs), Kansai International Airport has installed fixed electrical ground power units (GPUs) at aircraft parking spots to provide electricity and air conditioning. The airport requests airlines to use this system. In January 2010, Kansai International Airport became the first Japan-based airport to reduce the amount of time an aircraft can use its APU prior to its scheduled departure; the time was reduced to 15 minutes from the previous 30 minutes (New Kansai International Airport Company Ltd, 2014a, p.13).

Figure 13 presents the percentage uptake in FEGP usage amongst international carriers and the corresponding year-onyear changes (\%) at Kansai International
Airport from 2002-2015. As can be seen in Figure 13, the percentage of international airlines operating at the airport and utilizing FEGP have, following a relatively slow start, increased the adoption of the system, specifically since 2009 . The figure indicates the ratio of actual number of times (that is, flights) ground power units (GPUs) were provided compared to the number of opportunities to provide ground power for flights. For fiscal years 2001 to 2008 , the ratio indicates only stationary GPUs, whilst from fiscal year 2009 onward it also includes mobile units. Importantly, the calculations from fiscal year 2012 onward excludes low-cost carrier (LCC) airlines, which typically have shorter aircraft parking times.

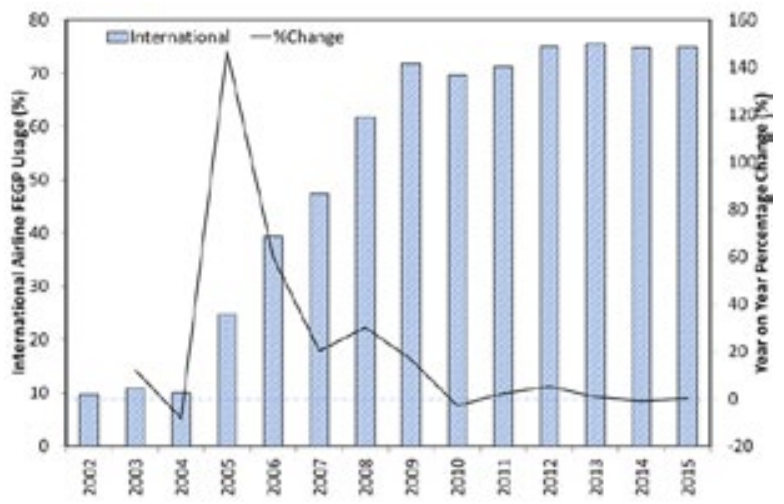

Fig. 13.

Annual International Airlines Ground Power Unit (GPU) Usage Ratio and Year-on-Year Change (\%): 2001-2015

Source: Data derived from (Kansai Airports, 2016)

Figure 14 presents the percentage uptake of FEGP for domestic airlines and the corresponding year-on-year change (\%) at Kansai International Airport from 2002-2015. The Japan-based, domestic, airlines serving the airport have historically adopted the use of the FEGP systems, with annual usage rates being more than 90 per cent during the period 2009- 2013. 


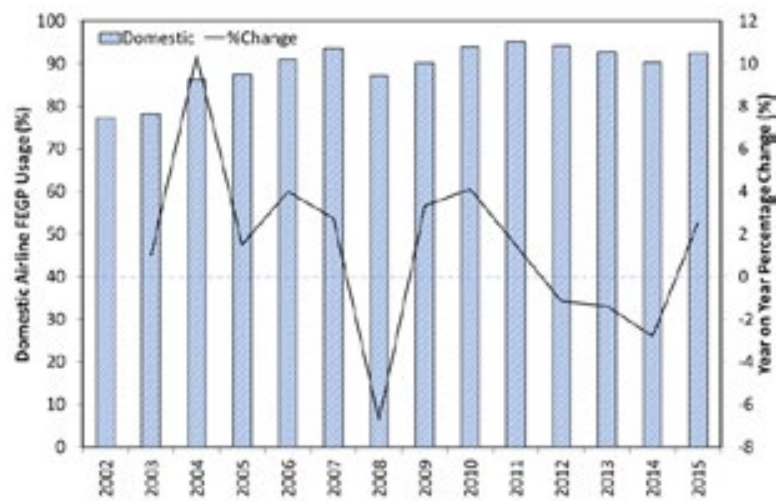

Fig. 14.

Annual Japanese-based Domestic Airlines Ground Power Unit (GPU) Usage Ratio and Year-on-Year Change (\%): 2002-2015

Source: Data derived from (Kansai Airports, 2016)

Figure 15 presents the FEGP uptake for all airlines (domestic/international) and the corresponding year-on-year changes (\%) at Kansai International Airport from 2002-2015.
Also, as can be observed in Figure 15, the total annual FEGP system usage is showing an upward trajectory, given the greater utilization of the system by airlines operating at the airport.

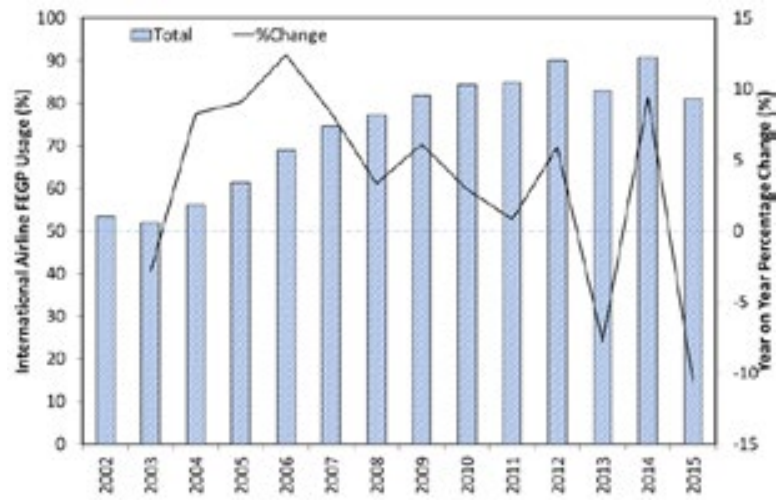

Fig. 15.

Total Annual Airlines Ground Power Unit (GPU) Usage Ratio and Year-on-Year Change (\%): 2002-2015 Source: Data derived from (Kansai Airports, 2016)

\subsubsection{Installation of Photovoltaic Systems}

Kansai International Airport has installed a solar power system as part of its sustainable energy management policy. A photovoltaic system with 358 panels has been installed on the roof of the medical products temperature-controlled building, which was constructed in September 2010, and is 
in the airport's international freight zone (New Kansai Airport Company Ltd, 2014a). In the 2012 fiscal year, the airport invited applications from electricity venders to install solar panels on the roofs of air cargo terminals as well as on the land adjacent to runways. The successful applicants were decided in April 2013. Panels were installed along planned taxiways expansion on the south side of Runway B and on the air cargo terminal roofs (New Kansai International Airport Company Ltd, 2013). The "KIX Megasolar" system has been generating electricity, since February 2014. About 70,000 solar panels have been installed. The system is anticipated to generate around 12 million kilowatt-hours of electricity. This is equivalent to around 7 per cent of the total electricity consumed at Kansai Airport (New Kansai Airport Company Ltd, 2014a).

In September 2015, photovoltaic panels with a capacity to generate around 1.2 megawatts of power commenced operations. These photovoltaic panels have been installed on the roof of a Phase 1 air cargo warehouse (New Kansai Airport Company Ltd, 2015a). The new photovoltaic system generated a total of 48,000KWh in the 2015 fiscal year (Kansai Airports, 2016).

\subsubsection{Reducing Vehicle Idling Times}

As an entity that is prescribed under Japan's Nitrogen Oxides and Particulate Matter Act, the airport is required to prepare a vehicleuse management plan to reduce emissions of nitrogen oxides $\left(\mathrm{NO}_{\mathrm{x}}\right)$ and particulate matter (PM) (New Kansai Airport Company Ltd, 2015a). To reduce vehicle idling times at the airport, signs and posters are displayed in parking lots and other public places at Kansai International Airport. The Smart Island Council also conducts a vehicle idling- prevention awareness campaign targeted at drivers and passengers at the airport during the annual International Environment Month (each June) (New Kansai Airport Company Ltd, 2014a).

\subsubsection{Wind Power Generation}

KIX Sora Park is located by Terminal 2. Since the 2012 fiscal year, Kansai International Airport's Sora Park has had three small wind turbine and solar powered lights (New Kansai Airport Company Ltd, 2014b). In July 2014, a small 5-kilowatt wind turbine commenced operations. In the 2014 fiscal year, the new turbine system generated around 1,191 kilowatts of electricity. This was the first time such a system had been installed at an airport in Japan and it is being used to conduct impact studies on such aspects as noise and low frequency sound and the verification of electricity generation capacity (New Kansai Airport Company Ltd, 2015a).

\section{Conclusion}

This study has examined the sustainable energy management at Osaka's Kansai International Airport. The study was underpinned by a longitudinal qualitative case study research design. The period of the study was from 2002 to 2015 . The qualitative data was analyzed using document analysis.

Kansai International Airport has multiple sources of power. Electricity and natural gas is sourced from the municipal authorities. The airport has installed photovoltaic systems, wind power turbines and has adopted the use of hydrogen as other key energy sources. Over the study period, the amount of electricity purchased has declined from $122,767 \mathrm{MWh}$ per annum 
in 2002 to $102,774 \mathrm{MWh}$ in 2015 . This is despite a significant increase in the number of passengers and aircraft movements at the airport. The energy consumption per passenger and per aircraft movement has also displayed a downward trend from 2010 to 2015. The airport also uses natural gas as an important energy source and the annual consumption was quite consistent from 2002 to 2013 , but in 2014 and 2015 the airport was required to purchase greater volumes of natural gas to satisfy its requirements. The annual amount of energy consumed for cooling from 2011 to 2015 has been around $241,450 \mathrm{GJ}$, which represented a significant reduction on the amount of energy consumed for cooling in the 2002 and 2003 fiscal years. The annual consumption of energy for heating oscillated quite significantly over the study period peaking in $2012(162,491 \mathrm{GJ})$ before declining in the three subsequent years. The annual consumption of energy for cooling in 2015 was $143,704 \mathrm{GJ}$.

Throughout the study period, Kansai International Airport has implemented a wide range of energy-saving measures on both the airside and landside precincts. The energy saving initiatives include the improved use of passenger terminal ceiling fans, a more efficient operation of the passenger terminal air conditioning system (using information technology), the introduction and use of hydrogen as a key energy source, the formation of an Energy Conservation Committee and the widespread use of light emitting diodes (LEDs). Other energy saving measures include the introduction of low emission vehicles by Kansai Airports, the airport operator, and other businesses operating at the airport and the promotion of the fixed electrical ground power systems (FEGP) for aircraft ground servicing. In addition, the airport has installed a large scale photovoltaic system (KIX Megasolar System) as well as wind powered system that is used for lighting in the airport's Sora Park precinct. In accordance with statutory requirements, the airport also conducts vehicle idling time awareness campaigns. Kansai Airports is also planning for its future and foresees the use of hydrogen and clean energy as playing a vital role as key energy sources, especially in the Second Phase Island Passenger Terminal precinct.

\section{References}

Akyüz, M.K.; Altuntaş, Ö.; Sögüt, M. Z. 2017. Economic and environmental optimization of an airport terminal building's wall and roof insulation, Sustainability 9(10): 1849.

Alba, S.O.; Manana, M. 2017. Characterization and analysis of energy demand patterns in airports, Energies 10(1): 119.

Anna Aero. 2014. Kansai International Airport Benefits from LCC Expansion from Peach Aviation and Jetstar Japan. Available from internet: <http://www.anna. aero/2014/11/19/kansai-international-airport-benefitsfrom-lcc-expansion/>.

Ashford, N.J.; Mumayiz, S.A.; Wright, P.H. 2011. Airport engineering: planning, design, and development of 21st century airports, Fourth Edition. John Wiley \& Sons, USA. 753 p.

Ashford, N.J., et al. 2013. Airport operations, Third Edition. McGraw-Hill, Inc. USA. 640 p.

Balachandar, G.; Roy, S.; Das, D. 2016. Production process via fermentation. In book (eds. Stolten, D., Emonts, B.) Hydrogen Science and Engineering: Materials, Processes, Systems and Technology. Wiley-VCH Verlag, Germany: 412-438. 
Barrett, S. 2015. Ownership structures and the implications for developing airport solar projects in the USA, Journal of Airport Management 9(3): 248-263.

Barrett, S., et al. 2014. Energy technologies' compatibility with airports and airspace: guidance for aviation and energy planners, Journal of Airport Management 8(4): 318-326.

Baxter, G.; Srisaeng, P.; Wild, G. 2018. An assessment of airport sustainability, part 1 -waste management at Copenhagen Airport, Resources 7(1): 21.

Budd, L.; Budd, T. 2013. Environmental technology and the future of flight. In book (eds. Budd, L., Griggs, S., Howarth, D.) Sustainable Aviation Futures. Emerald Group Publishing, UK: 87-107.

Cardona, E.; Piacentino, A.; Cardona, F. 2006. Energy saving in airports by trigeneration. part I: assessing economic and technical potential, Applied Thermal Engineering 26(14-15): 1427-1436.

Climates to Travel. 2018. World Climate Guide: Climate - Osaka. Available from internet: <https:// www.climatestotravel.com/climate/japan/osaka $>$.

Court, M. 2010. Longitudinal research. In book (eds. Mills, A.J., Durepos, G., Wiebe, E.) Encyclopedia of Case Study Research. Sage Publications, UK: 535-538.

Dempsey, P.S. 2000. Airport planning and development handbook: a global survey. McGraw-Hill, Inc. USA. 589 p.

Dincer, I.; Joshi, A.S. 2013. Solar based hydrogen production systems. Springer, USA. $141 \mathrm{p}$.

Doganis, R. 2005. The airportbusiness. Routledge, UK. 227 p.

Edgington, D.W.2000. City profile: Osaka, Cities 17(4): 305-318.

Ehiorobo, R. 2017. Electrification of Emuhun Village in Edo State, Nigeria using renewable mix. Dorrance Publishing Company, USA. 386 p.
Freyssinier, J.P. 2014. The long-term performance of LEDs, International Airport Review 18(2): 38-41.

Furudoi, T. 2010. The second phase construction of Kansai International Airport considering the large and long-term settlements of the clay deposits, Soils and Foundations 50(6): 805-816.

Gellings, C.W. 2011. Saving energy and reducing $\mathrm{CO}_{2}$ emissions with electricity. The Fairmont Press, USA. 291 p.

Graham, A. 2014. Managing airports: an international perspective, Fourth Edition. Routledge, UK. 344 p.

Hair, J.F. Jr. et al. 2015. Essentials of business research methods, Second Edition. Routledge, Abingdon, UK. $467 \mathrm{p}$.

Hassett, M.; Paavilainen-Mäntymäki, E. 2013. Longitudinal research in organizations: an introduction. In book (eds. Hasset, M., Paavilainen-Mäntymäki, E.) Handbook of Longitudinal Research Methods in Organisation and Business Studies. Edward Elgar Publishing, UK: 1-22.

International Airport Review. 2010. UK Airport Operators Launch New Guidelines to Reduce Aircraft Ground Emissions. Available from internet: <http:// www.internationalairportreview.com/2717/airportnews/uk-airport-operators-launch-new-guidelines-toreduce-aircraft-ground-emissions/>.

International Civil Aviation Organization. 2017. Presentation of 2016 Air Transport Statistical Results. Available from internet: <https://www.icao.int/ annual-report-2016/Documents/ARC_2016_Air\%20 Transport\%20Statistics.pdf $>$.

Ishikura, T.; Sugimura, Y.; Ishii, M. 2005. Fiscal characteristics of Incheon International Airport and Kansai International Airport. In Proceedings of the Eastern Asia Society for Transportation Studies, 5: 520-532.

Janić, M. 2011. Greening airports: advanced technology and operations. Springer-Verlag. 206 p. 
Kansai Airports. 2016. Smart Island Report 2016. Available from internet: <http://www.kansai-airports. co.jp/en/efforts/environment/kix/smart-island/file/ smart_rprt16.pdf $>$.

Kansai Airports. 2018a. Airport Facilities Information. Available from internet: <https://www.kansai-airport. or.jp/en/map/guidance.html>.

Kansai Airports. 2018b. Kansai International Airport Statistics. Available from internet: <http://www.kansaiairports.co.jp/en/company-profile/about-airports/ kix.html>.

Kansai International Airport Company Ltd. 2007. Kansai International Airport Eco-Island Environmental Report 2007. Available from internet: <http://www. kansai-airports.co.jp/en/efforts/environment/kix/ smart-island/file/kixeco_rprt07.pdf $>$.

Kansai International Airport Company, Ltd. 2012. Kansai International Airport Environmental Management Project. Available from internet: <http:// www.kiac.co.jp/pdf/report_EMP_en.pdf $>$.

Kazda, T.; Caves, R.E. 2015. Airport design and operation, Third Edition. Emerald Group Publishing, UK. 596 p.

Kazda, T.; Caves, B.; Kamenický, M. 2015. Environmental control. In book (eds. Kazda, A., Caves, R.E.) Airport Design and Operation, Third Edition. Emerald Group Publishing, UK: 457-500.

Lancaster, G. 2005. Research methods in management. Elsevier Butterworth-Heinemann, UK. 258 p.

Larminie, J.; Lowry, J. 2012. Electric vehicle technology explained, Second Edition. John Wiley \& Sons, USA. 314 p.

Love, P. 2003. Document analysis. In book (eds. Stage, F.K., Manning, K.) Research in the College Context: Approaches and Methods. Brunner-Routledge, USA: 83-96.
McGormely, R.W.2011. Guidebook of practices for improving environmental performance at small airports. ACRP Report 43. Transportation Research Board, USA. 356 p.

Moorman, R.W. 1994. Osaka to me, Air Transport World 31(10): 62-65.

Morikawa, Y.; Tabata, T.; Emura, T. 2007. Ground improvement for the second phase construction of Kansai International Airport. In book (eds. Kikuchi et al.) Advances in Deep Foundations: International Workshop on Recent Advances of Deep Foundations. Taylor \& Francis, Netherlands: 389-394.

Morris, P.L. 2017. Triangulation. In book (ed. Allen, M.) The SAGE Encyclopedia of Communication Research Methods. SAGE Publications, USA: 1781-1783.

New Kansai International Airport Company Ltd. 2013. KIX Eco-Island Environmental Report 2013. Available from internet: <http://www.kansai-airports. co.jp/en/efforts/environment/kix/smart-island/file/ kixeco_rprt13.pdf $>$.

New Kansai International Airport Company, Ltd. 2014a. Environmental Report 2014. Available from internet: <http://www.kansai-airports.co.jp/en/efforts/ environment/file/envreport2014.pdf $>$.

New Kansai International Airport Company, Ltd. 2014b. Smart Island Report 2014. Available from internet: <http://www.kansai-airports.co.jp/en/efforts/ environment/kix/smart-island/file/smart_rprt14.pdf $>$.

New Kansai International Airport Company, Ltd. 2015a. Environmental Report 2015. Available from internet: <http://www.kansai-airports.co.jp/en/efforts/ environment/file/envreport2015.pdf $>$.

New Kansai International Airport Company, Ltd. 2015b. Creating the Future with Hydrogen: Smart Airport KIX. Available from internet: <http://www. kansai-airports.co.jp/en/efforts/environment/kix/ smart-island/file/smart_airport.pdf $>$. 
Oates, B.J. 2006. Researching information systems and computing. SAGE Publications, UK. 360 p.

Payne, G.; Payne, J. 2004. Key concepts in social research. SAGE Publications, UK. 224 p.

Preston, K. 2015. Sustainability initiatives helping airports address climate change, International Airport Review 19(5): 16-19.

Rahim, A. R.; Baksh, M. S. 2003. Case study method for new product development in engineer-to-order organisations, Work Study 52(1): 25-36.

Ramon Gil-Garcia, J. 2012. Enacting electronic government success: an integrative study of government-wide websites, organizational capabilities, and institutions. Springer Science-Business Media, USA. 254 p.

Scott, J.; Marshall, G. 2009. A dictionary of sociology, Third Edition. Oxford University Press, UK. 816 p.

Testa, E., et al. 2014. Analysis of environmental benefits resulting from the use of hydrogen technology in handling operations at airports, Clean Technologies and Environmental Policy 16(5): 875-890.

Thomas, C.; Hooper, P. 2013. Sustainable development and environmental capacity of airports. In book (eds. Ashford et al.) Airport Operations, Third Edition. McGrawHill, Inc. USA: 553-578.
Tsutsui, Y. 2013. Weather and individual happiness, Weather Climate and Society 5: 70-82.

Vanker, S.; Enneveer, M.; Mäsak, M. 2013. Implementation of environmentally friendly measures at Tallinn Airport, Aviation 17(1): 14-21.

Wu, C.L. 2016. Airline operations and delay management: insights from airline economics, networks and strategic schedule planning. Routledge, UK. 254 p.

Yeang, K.; Woo, L. 2010. Dictionary of ecodesign: an illustrated reference. Routledge, UK. 294 p.

Yim, S.H.L.; Stettler, M.E.J.; Barrett, S.R.H. 2013. Air quality and public health impacts of UK airports. Part II: impacts and policy assessment, Atmospheric Environment 67: 184-192.

Yin, R. K. 2009. Case study research: design and methods, Fourth Edition. SAGE Publications, USA. 219 p.

Yin, R. K. 2017. Case study research: design and methods, Fifth Edition. SAGE Publications, USA. 312 p.

Ziębik, A.; Hoinka, K. 2013. Energy systems of complex buildings. Springer-Verlag, UK. 346 p. 